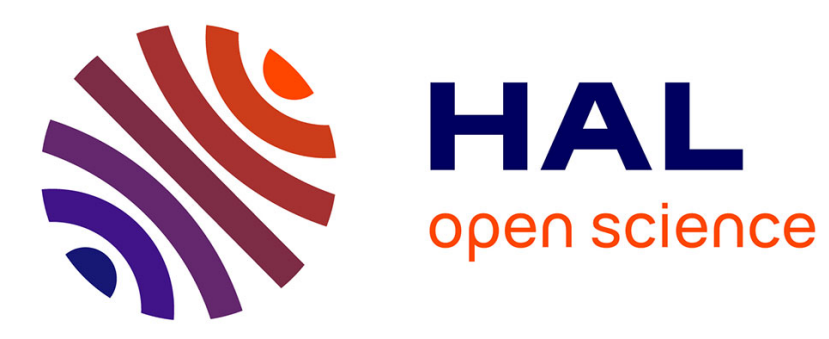

\title{
Diagnosis and management of ophthalmologic features in patients with mucopolysaccharidosis
}

Stefano Ferrari, Diego Ponzin, Jane L Ashworth, Kristina Teär Fahnehjelm, C Gail Summers, Paul R Harmatz, Maurizio Scarpa

\section{- To cite this version:}

Stefano Ferrari, Diego Ponzin, Jane L Ashworth, Kristina Teär Fahnehjelm, C Gail Summers, et al.. Diagnosis and management of ophthalmologic features in patients with mucopolysaccharidosis. British Journal of Ophthalmology, 2010, 95 (5), pp.613. 10.1136/bjo.2010.179937 hal-00588352

\section{HAL Id: hal-00588352 https://hal.science/hal-00588352}

Submitted on 23 Apr 2011

HAL is a multi-disciplinary open access archive for the deposit and dissemination of scientific research documents, whether they are published or not. The documents may come from teaching and research institutions in France or abroad, or from public or private research centers.
L'archive ouverte pluridisciplinaire HAL, est destinée au dépôt et à la diffusion de documents scientifiques de niveau recherche, publiés ou non, émanant des établissements d'enseignement et de recherche français ou étrangers, des laboratoires publics ou privés. 


\section{Diagnosis and management of ophthalmologic features in patients with}

\section{mucopolysaccharidosis}

Stefano Ferrari ${ }^{1}$, Diego Ponzin ${ }^{1}$, Jane L. Ashworth ${ }^{2}$, Kristina Teär Fahnehjelm ${ }^{3}$, C. Gail

Summers ${ }^{4}$, Paul R. Harmatz ${ }^{5}$, Maurizio Scarpa ${ }^{6}$

1. The Veneto Eye Bank Foundation, Venice, Italy

2. Manchester Royal Eye Hospital, Manchester, UK

3. Department of Clinical Neuroscience, Karolinska Institutet and Department of Paediatric Ophthalmology and Strabismus, St. Erik Eye Hospital, Karolinska University Hospital, Huddinge, Sweden

4. Departments of Ophthalmology and Pediatrics, University of Minnesota, Minneapolis, MN, USA

5: Children's Hospital \& Research Center Oakland, Oakland, CA, USA

6. Department of Paediatrics, University of Padua, Padua, Italy

\section{Corresponding author:}

Maurizio Scarpa

Department of Paediatrics, University of Padua

Via Giustiniani 3

35128 Padua

Italy

Tel.: +390498213505

Fax: +390498213502

e-mail: scarpa@pediatria.unipd.it 
Keywords: Diagnosis, Eye Diseases, Glycosaminoglycans, Mucopolysaccharidoses, Treatment

Keyword selection in submission from fixed list: pathology, imaging, diagnostic tests/investigation, treatment medical, child health (paediatrics)

Word count: 3254

Word count abstract: 228. 


\section{SUMMARY}

Ocular pathology is common in patients with mucopolysaccharidosis (MPS), an hereditary lysosomal storage disorder, where the eye as well as other tissues accumulate excessive amounts of glycosaminoglycans. Despite genetic and phenotypic heterogeneity within and between different types of MPS, the disease symptoms and clinical signs often manifest during the first six months of life with increasing head size, recurrent infections, umbilical hernia, growth retardation and skeletal problems. Typical ocular features include corneal clouding, ocular hypertension/glaucoma, retinal degeneration and optic nerve atrophy. Visual deterioration and sensitivity to light may substantially reduce the quality of life in MPS patients, particularly when left untreated.

As an early intervention, haematopoietic stem cell transplantation and/or enzyme replacement therapy are likely to improve patients' symptoms and survival, as well as visual outcome. Thus, it is of utmost importance to ensure proper detection and accurate diagnosis of MPS at an early age. Fundamental herein is to increase awareness and knowledge among ophthalmologists of the ocular problems affecting MPS patients and to highlight potential diagnostic pitfalls and difficulties in patient care.

This review provides insight into the prevalence and severity of ocular features in patients with MPS and gives guidance for early diagnosis and follow-up of MPS patients. MPS poses therapeutic challenges in ocular management, which places ophthalmologists next to paediatricians at the forefront of interventions to prevent long-term sequelae of this rare but serious disease. 


\section{The clinical features of mucopolysaccharidoses}

The mucopolysaccharidoses (MPS) are a heterogeneous group of lysosomal storage disorders that are genetically inherited in an autosomal recessive manner (except for MPS II which is X-linked).[1] These inborn metabolic diseases are characterised by functional defects in particular lysosomal enzymes, involved in the breakdown of glycosaminoglycans (GAGs, acid mucopolysaccharides) (Table 1).[1] Depending on the type of MPS, the resulting catabolic error causes progressive accumulation of particular GAGs in lysosomes and their abnormally high excretion in urine (Table 1).[1] Histochemical examinations have demonstrated cytoplasmic membrane-bound vacuoles containing GAGs in almost all ocular tissues of MPS patients.[2,3] These deposits alter the cellular shape and tissue ultrastructure, resulting in progressive physiological dysfunction that presents clinically at a young age and ultimately can cause visual impairment or blindness.[3,4] Accumulation of GAGs in other organs are the cause of typical coarse facial features, skeletal deformities (e.g., dysostosis multiplex), growth retardation (often accelerated in the first 12-18 months), cardiac valvular abnormalities, respiratory difficulties and gastrointestinal problems (e.g., hepatosplenomegaly, bowel dysfunction) as well as intellectual and behavioural impairment (in the severe forms of MPS I, II and III) (fig 1).[3] About 70\% of patients have central nervous system involvement, albeit to different extents. Ocular manifestations vary and include corneal clouding, ocular hypertension/glaucoma, retinal degeneration and optic nerve swelling with subsequent atrophy. The severity and relative predominance of the ocular features, depend on the MPS (sub)type (Table 1).[3] Nevertheless, phenotypic variation is often observed,[3] which is likely due to the mutational heterogeneity of the enzyme involved,[5,6] that may lead to absent or attenuated enzyme activity.[5,7] Further mutational analysis studies may reveal potential genotype-phenotype correlations. 
Table 1. Classification of different MPS types according to enzyme deficiency and with indication of the severity of ocular pathologies (slightly adapted from Ashworth et al.[3]*) Note that there are inter-patient variations

\begin{tabular}{|c|c|c|c|c|c|c|}
\hline \multirow[t]{2}{*}{ MPS type (eponym) } & \multirow[t]{2}{*}{ Enzyme deficiency } & \multirow{2}{*}{$\begin{array}{l}\text { Involved } \\
\text { GAG }\end{array}$} & \multicolumn{4}{|c|}{ Eye diseases } \\
\hline & & & Corneal clouding & Glaucoma & Retinopathy & $\begin{array}{l}\text { Optic nerve } \\
\text { abnormalities }\end{array}$ \\
\hline MPS I H (Hurler) & $\alpha$-L-iduronidase & DS, HS & +++ & ++ & ++ & ++ \\
\hline $\begin{array}{l}\text { MPS I H/S } \\
\text { (Hurler-Scheie) }\end{array}$ & $\alpha$-L-iduronidase & DS, HS & ++ & ++ & ++ & ++ \\
\hline MPS I S (Scheie) & $\alpha$-L-iduronidase & DS, HS & + & + & ++ & + \\
\hline MPS II (Hunter) & iduronate-2-sulfatase & DS, HS & + & + & ++ & ++ \\
\hline $\begin{array}{l}\text { MPS III (Sanfilippo) } \\
\text { A-B-C-D }\end{array}$ & $\begin{array}{c}\text { heparan sulfamidase (A) } \\
\text { N-acetyl- } \alpha \text {-D-glucosaminidase (B) } \\
\text { acetyl-CoA- } \alpha \text {-glucosaminidase } \\
\text { N-acetyltransferase (C) } \\
\text { N-acetylglucosamine-6-sulfatase (D) }\end{array}$ & HS & + & + & +++ & + \\
\hline MPS IV A (Morquio A) & $\mathrm{N}$-acetylgalactosamine-6-sulfatase & KS & + & + & ++ & + \\
\hline $\begin{array}{l}\text { MPS VI } \\
\text { (Maroteaux-Lamy) }\end{array}$ & $\mathrm{N}$-acetylgalactosamine-4-sulfatase & DS & +++ & ++ & unknown & ++ \\
\hline MPS VII (Sly) & $\beta$-D-glucuronidase & DS, HS, CS & ++ & unknown & unknown & ++ \\
\hline MPS IX (Natowicz) & hyaluronidase & $\mathrm{CS}$ & unknown & unknown & unknown & unknown \\
\hline
\end{tabular}

+: mild; ++: moderate; +++: severe; CS: chondroitin sulfate; DS: dermatan sulfate; GAG: glycosaminoglycan; HS: heparan sulfate; KS: keratan sulfate 


\section{Call for early detection and diagnosis of MPS}

Early detection allows prompt intervention of this devastating disorder in a primary stage with haematopoietic stem cell transplantation (HSCT) and/or enzyme replacement therapy (ERT) and thus, better prognosis and outcomes for the patient. While a rapid colorimetric screening of the urinary GAG expression level is quite predictive, $[7,8]$ the definitive diagnosis is mostly based upon a combination of clinical, radiological and laboratory (e.g., specific lysosomal enzyme activity assay) methods from collaborative medical specialties.[3,7]

Given its phenotypic heterogeneity and its rarity, with an overall cumulative incidence rate of 2 to 5 patients with MPS out of 100,000 live births, $[9,10]$ medical awareness of MPS is essential in order to allow proper and timely diagnosis. Despite great variations in severity and associated progression rate of MPS (fig 1), the disease can manifest within the first 6 months of age, leading to limited life span, particularly for rapidly-progressing disease forms. Although paediatricians often encounter and recognise patients with MPS, patients with the attenuated form (e.g., MPS I S that present at later ages - older than 5 years) may be first seen and diagnosed by ophthalmologists because of the eye involvement.[3] Patients less than 5 years old with a severe form (MPS I H) have been described, who were not diagnosed until glaucoma developed.[11] These findings highlight the crucial role of ophthalmologists in contributing to early detection of MPS in children.

\section{Ocular problems in MPS}

Anterior segment

Corneal clouding can involve all layers of the cornea including the epithelium, stroma and endothelium. Structural alterations caused by GAG deposition, including an abnormal cell 
shape and irregular collagen fibril diameter, spacing and arrangement in the stroma, result in reduced transparency and increased light scattering.[3,12] Corneal clouding varies from being subtle to severe and is often described as being of ground glass appearance. It typically has a diffuse pattern,[2] although primarily peripheral corneal clouding has been described in MPS I S.[13] A moderately positive correlation between corneal clouding and central corneal thickness has been reported,[14] although this has not been corroborated by others.[15] Progressive corneal clouding is a prominent feature of patients with MPS I, VI and VII (Table 1, fig 2). $[3,4]$ It may first be asymptomatic and then present as photophobia associated with slowly progressive loss of visual acuity.[16] Signs and symptoms reported from the MPS I Registry revealed that corneal clouding is common, being present in over $80 \%$ of the patients, regardless of age at onset.[17] All 19 patients with MPS VI in a Brazilian study showed corneal clouding that ranged from mild to severe.[18] This high prevalence of corneal clouding in MPS was further confirmed by a retrospective case series, which found that MPS VI patients were more severely affected than MPS I patients (Table 2). [4] In addition to corneal clouding, peripheral vascularisation of the cornea may also be present in MPS patients.[3,19] This can occur following chronic corneal oedema due to raised intraocular pressure (IOP), or secondary to corneal exposure associated with pseudo-exophthalmos (fig 2) and/or post-treatment graft-versus-host disease.[3] Both superficial and deep vessels were observed in all four cases with glaucoma in association of MPS VI.[19]

Open-angle[11,19,20] and acute/chronic angle-closure glaucoma[19,21,22] have both been observed in MPS patients (Table 1). GAG accumulation and the consequent thickening of the cornea can lead to narrowing of the anterior chamber angle, and deposition within trabecular cells may cause obstruction of outflow.[11,19] Another potential cause of angle closure and subsequent increased IOP is the development of multiple iridociliary cysts.[23] The prevalence of glaucoma is estimated at $10 \%$ for the MPS I population.[17] While ocular 
hypertension and glaucoma are fairly rare in other types of MPS, elevated IOP was observed in approximately half of the patients with MPS VI (Table 2) and could be due to their corneal changes because a statistically significant relationship between IOP and corneal clouding has been found.[4] This illustrates the difficulty in distinguishing increased corneal rigidity and thickness from true raised IOP and potential glaucoma. Only one patient with MPS VI, however, had an enlarged cup-to-disc ratio.[4]

Posterior segment

Ultrasound examinations in 65 patients with MPS have demonstrated significantly thicker sclera at the posterior pole and a widened optic nerve and its sheath.[24] These morphological changes probably develop very early in the course of the disease.[24] Thickened sclera may subsequently lead to vortex vein obstruction and development of the uveal effusion syndrome as described in one patient with MPS II.[25]

Optic disc and optic nerve pathologies are present in MPS (Table 1). Optic disc swelling of mild-to-moderate severity was noted in $50 \%$ of the patients with MPS VI, while optic nerve atrophy in 2 of 14 cases.[4] Similar rates for MPS VI were observed in a study by Collins et al, while optic nerve atrophy was slightly more common in MPS I H and I H/S patients (Table 2).[26] Optic disc swelling (i.e., papilloedema) and subsequent optic nerve atrophy can occur secondary to high intracranial pressure (ICP)[4], or follow nerve compression due to GAGthickened dura and sclera.[27] Alternative causes of optic nerve atrophy may be the degeneration of optic nerve ganglion cells due to intracellular GAG deposition or optic disc cupping and atrophy due to increased IOP.[27]

Retinopathy occurs as a result of GAG deposition within retinal pigment epithelial (RPE) cells and in the inter-photoreceptor matrix, leading to progressive photoreceptor loss, retinal 
degeneration and dysfunction (fig 2).[4] This may clinically appear as sensitivity to light, central or peripheral vision loss, clumsiness, night blindness, etc.,[3] and display an identical histopathology to retinitis pigmentosa.[2] Variable degrees of retinopathy, with associated changes in the electroretinogram (ERG), have predominantly been seen in MPS I, II and III (Table 1, Table 2).[4,28] ERG evidence of retinal dysfunction ranged from none to severe for MPS I and II patients, while all MPS III patients demonstrated moderately-to-severely affected ERGs.[28] The ERG findings were similar to those seen in primary and secondary rod-cone retinal degeneration, where the depression of rod-mediated responses exceeds that of the cone system,[15,28,29] causing a reduction in b-waves on dark adaptation.[30] In several cases, ophthalmological signs and symptoms did not correlate with the electrophysiological findings; funduscopic findings were restricted to only mild changes of the RPE or vascular attenuation.[28] Thus, as in any other disease, ophthalmological examination is not sufficient to rule out retinal involvement in MPS.[28] Lastly, macular oedema and maculopathy has been reported in MPS I S and MPS II.[31,32]

Best-corrected visual acuity (BCVA) differs in patients with MPS. Whereas a BCVA of at least 0.5 in more than half (58\%) of the Swedish MPS I patients was found (Fahnehjelm KT et al, accepted by Acta Ophthalmol 2010), other reports demonstrated a high rate of visual impairment in patients with MPS I (Table 2). $[4,14]$ This distinction could be caused by phenotypic variations, variable age at examination or diagnosis, and consequent compliance with correction of the high hypermetropia or treatment of amblyopia. Also patients with MPS VI can suffer from visual impairment (Table 2).[4] In addition, patients with both MPS VI and MPS I have been reported with amblyopia, ranging between 32 and $44 \%$ of the patients, and strabismus, ranging between 25 and 44\%.[4] Refractive errors are also common in patients with MPS. The majority (> 90\%) of patients with MPS I (of either sub-type) and MPS VI for whom refraction data were available had hypermetropia.[4,33-35] It has been 
speculated that hypermetropia is caused by GAG-mediated increased rigidity of the cornea, thereby straightening its curvature and reducing its refractive power.[33] Hypermetropia could also result from scleral thickening and shortened axial length (Fahnehjelm KT et al, accepted by Acta Ophthalmol 2010). 
Table 2. Prevalence of ocular features in patients with MPS I and VI (expressed as \% of affected patients unless indicated otherwise)

\begin{tabular}{|c|c|c|c|c|c|c|}
\hline MPS type & $\begin{array}{l}\text { Corneal } \\
\text { clouding[4] } \\
+;++;+++\end{array}$ & 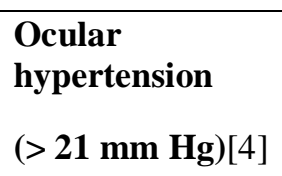 & $\begin{array}{l}\text { Optic disc } \\
\text { swelling }[26]^{\#}\end{array}$ & Optic atrophy $[26]^{\#}$ & Retinopathy[4] & $\begin{array}{l}\text { Visual impairment } \\
(<\mathbf{2 0 / 4 0 *})[4]\end{array}$ \\
\hline MPS I H & $\begin{array}{l}\mathrm{N}=19 \\
47 \% ; 37 \% ; 16 \%\end{array}$ & $\begin{array}{l}\mathrm{N}=19 \\
5 \%\end{array}$ & $\begin{array}{l}\mathrm{N}=14 \\
57 \%\end{array}$ & $\begin{array}{l}\mathrm{N}=14 \\
14 \%\end{array}$ & $\begin{array}{l}\mathrm{N}=13 ; 69 \%(\text { ERG }) \\
\mathrm{N}=19 ; 11 \% \text { (atrophy) }\end{array}$ & $\begin{array}{l}\mathrm{N}=19 \\
79 \%\end{array}$ \\
\hline MPS I H/S & $\begin{array}{l}\mathrm{N}=8 \\
38 \% ; 38 \% ; 25 \%\end{array}$ & $\begin{array}{l}\mathrm{N}=9 \\
11 \%\end{array}$ & $\begin{array}{l}\mathrm{N}=21 \\
43 \%\end{array}$ & $\begin{array}{l}\mathrm{N}=21 \\
19 \%\end{array}$ & $\begin{array}{l}\mathrm{N}=1 ; 1 \text { patient }(\mathrm{ERG}) \\
\mathrm{N}=9 ; 56 \% \text { (atrophy) }\end{array}$ & $\begin{array}{l}\mathrm{N}=9 \\
44 \%\end{array}$ \\
\hline MPS I S & $\begin{array}{l}\mathrm{N}=3 \\
2 \text { patients; 1patient; } \\
\text { none }\end{array}$ & $\begin{array}{l}\mathrm{N}=3 \\
\text { none }\end{array}$ & $\begin{array}{l}\mathrm{N}=4 \\
\text { none }\end{array}$ & $\begin{array}{l}\mathrm{N}=4 \\
\text { none }\end{array}$ & $\begin{array}{l}\text { NA (ERG) } \\
\mathrm{N}=3 ; 2 \text { patients (atrophy) }\end{array}$ & $\begin{array}{l}\mathrm{N}=3 \\
\text { none }\end{array}$ \\
\hline MPS VI & $\begin{array}{l}\mathrm{N}=16 \\
31 \% ; 25 \% ; 38 \%\end{array}$ & $\begin{array}{l}\mathrm{N}=13 \\
54 \%\end{array}$ & $\begin{array}{l}\mathrm{N}=12 \\
42 \%\end{array}$ & $\begin{array}{l}\mathrm{N}=12 \\
8 \%\end{array}$ & $\begin{array}{l}\mathrm{N}=8 ; 12 \%(\mathrm{ERG}) \\
\mathrm{N}=16 ; 0 \% \text { (atrophy) }\end{array}$ & $\begin{array}{l}\mathrm{N}=16 \\
25 \%\end{array}$ \\
\hline
\end{tabular}

*vision worse than 6/12 Snellen equivalent in the better eye

\#values relate to eyes, not patients

ERG: electroretinogram; NA: not available; +: mild; ++: moderate; +++: severe 


\section{Assessment and diagnosis of eye disorders in MPS}

An accurate diagnosis of the ocular manifestations in MPS patients may be a challenge because of poor cooperation of the patient and due to the different underlying ocular and other pathologies.[4] Severe photophobia may hamper clinical examination in general,[33] while the corneal involvement in MPS may make diagnosis of glaucoma difficult.

Firstly, thickening and increased corneal rigidity can falsely elevate the IOP values.[14,36] This effect on IOP validity is more observed in non-contact tonometry than in Goldman applanation tonometry.[36] In that sense, dynamic contour tonometry that uses the principle of corneal contour matching instead of applanation may be more reliable and suitable for patients with MPS.[37] Given its possible impact on IOP, it is certainly worthwhile to assess the corneal thickness by pachymetry.[38]

Secondly, another frequently encountered difficulty when assessing glaucoma is related to corneal clouding, which hampers a clear view by ophthalmoscopy and gonioscopy, limiting the assessment of optic disc cupping (i.e., cup-to-disc ratio) and visualisation of the drainage angle.[19,21] Similarly, corneal clouding can also lead to difficulties in diagnosing and monitoring papilloedema, optic nerve atrophy and retinal or macular degeneration by funduscopic examination after dilatation or by optical coherence tomography that can distinguish the different retinal layers.[39] Therefore, ultrasound examination may be a valuable and suitable alternative to obtain better image quality in patients with MPS. In addition, an electroretinography (ERG) examination aids diagnosis of retinopathy. To recognise corneal clouding as a clinical feature of MPS and discriminate it from other diseases (e.g., congenital glaucoma, staphylococcal hypersensitivity, cystinosis, corneal dystrophy), visualisation of the in vivo microstructure of the cornea with real-time, slitscanning confocal microscopy is preferable to histological techniques.[40] Brighter 
intercellular spaces in all corneal layers and microdeposits of 1.0 to $3.8 \mu \mathrm{m}$ outside and inside stromal keratocytes that appear rounded with clearly demarcated hyporeflective regions are characteristic features found in MPS I and MPS VI patients.[40-42]

In addition, the diagnostic assessment of ocular pathologies is frequently complicated by the patients' physical inabilities, young age and developmental delay (behavioural or intellectual disabilities), particularly when cooperation is needed for visual field measurements.[3] Sometimes, an ERG examination under sedation or anaesthesia to determine severity of retinopathy can be helpful. General anaesthesia, however, can be dangerous in patients with MPS due to co-existent cardiovascular or respiratory problems (severe oro-pharyngeal and upper airway narrowing) [43]. This leads to problems with intubation and pre-/post-operative complications,[43-45], requiring an experienced anaesthesiologist (for children with MPS).[46]. Retinoscopy is also hampered in the anaesthetised child as the correct axis can only be approximated, which can be a major source of error. Therefore, simple clinical tests (e.g., colour vision Hardy Rand Rittler and Cone Adaptation Test) can be used in the office for initial screening of retinal pathology. Upon suspicion of retinal pathology, ERG under general anaesthesia may be considered.

Recording of visual evoked potentials (VEPs) is more easily performed. In patients with severe corneal clouding, flash VEPs show a decreased signal, while optic nerve pathologies due to increased ICP may reflect in attenuated amplitudes or delayed latencies of the VEPs. However, it is worth noting that normal VEPs may be found in patients with swollen optic discs in early (not chronic) stages.

International expert panels have recommended that MPS patients are evaluated on a regular basis for their ophthalmic problems, i.e., at least every 12 months for MPS I and MPS VI, and according to the individual patient's needs as determined by the treating physician.[17,27]. 
Apart from more specific investigations such as pachymetry, ultrasound examination and electrophysiology when needed, basic clinical follow-ups in children with MPS should include evaluation by an orthoptist to detect strabismus, evaluation of IOP, retinoscopy after cycloplegia to detect high refractive errors, and evaluation of the fundi, including photography in the cooperative patient.

\section{Therapeutic approaches in MPS and its ocular features}

Integrated medical care necessitates a multi-disciplinary expert approach in the treatment of patients with MPS.[1,3] Input from different paediatric sub-specialties, including ophthalmology, is important and needs to consider the risk-benefit balance of treatment.[1] Because many patients with MPS are at increased anaesthetic risk,[44,45] local anaesthesia is often preferable, though age and mental status are relative deterrents,[45] and any procedure with sedation must be performed in a specific referral centre.

Ocular therapies in MPS

The predominance of corneal clouding, glaucoma and concomitant visual deterioration in MPS necessitates thorough clinical examinations, prescription of optimal correction and if needed, corneal transplantation and glaucoma treatment. To correct corneal clouding, penetrating keratoplasty (PK) (fig 3) or, more advanced techniques such as lamellar keratoplasty, are valuable treatment options in the absence of retinal degeneration (Pinello L et al, submitted to Clin Exp Ophthalmol). Deep anterior lamellar keratoplasty is currently favoured over conventional PK in MPS patients because of similar effectiveness and lower risks.[47] Although no systematic studies on the outcome of keratoplasty in patients with 
MPS have been performed, good results with the maintenance of clear donor cornea for a period of 3 months up to 5 years (without systemic therapies) were obtained in various cases.[48-52] However, while clearing of the host cornea has been noted,[53] GAGs may reaccumulate in the grafted tissue.[49,54] Re-opacification, as early as one year postsurgery[49,54], likely correlates with disease severity[49] and could be attributable to anterior-posterior spread of host keratocytes and gradual replacement of epithelial cells by host epithelium.[54] In addition, concomitant retinal degeneration, optic nerve atrophy, glaucoma or other dysfunctions may limit the success of PK in terms of visual improvement (fig 3).[3,49] Therefore, the potential benefits to vision and quality of life, even if temporary, must be weighed against co-existent eye pathologies, anaesthetic risks, intensive postoperative care and risk of complications in patients with MPS.[3]

When glaucoma is suspected - bearing influencing factors in mind and taking diagnostic difficulties into account - balancing the pros and cons of anti-glaucoma therapy[55] is similarly important. Clinical reports of anti-glaucoma therapy in patients with MPS are scarce and relatively dated.[11,19-22,29] This finding highlights the rarity of the MPS disorder and the difficulty in identifying glaucoma in MPS patients, because co-existent corneal clouding frequently hampers gonioscopy and ophthalmoscopy and because visual fields are usually not obtained.[19,21]

Systemic therapies in MPS

Disease-specific systemic therapies, i.e., HSCT and ERT, re-establish the regular GAG catabolism in the body. With the aim to reverse, arrest or at least slow down disease progression and considerably improve the patients' outcome and quality of life, [3] it is 
advantageous to start treatment early in life (i.e., HSCT before 24 months of age and ERT shortly after birth).[29,34,35,56-59] Such necessitates early diagnosis.

HSCT encompasses the transplantation of matched healthy donor cells (from bone marrow or umbilical cord blood) and has achieved beneficial effects on ocular problems, although not uniformly or in the long term.[15,29,33] Indeed, HSCT has been reported to reduce but not fully eliminate corneal clouding,[15,29,33] to resolve optic nerve oedema[15,29], and to improve ERG results.[29] (Summers CG et al, submitted to Clin Exp Ophthalmol) However, retinal degeneration can progress despite engraftment[29] and visual function may remain compromised.[33] (Summers CG et al, submitted to Clin Exp Ophthalmol) HSCT requires a suitable donor and there is significant risk of post-transplantation systemic morbidity and mortality (e.g., infection, graft-versus-host-disease, rejection and complications from adjuvant radiation or chemotherapy).[3,27] In addition, ocular complications may arise following HSCT, e.g., cataracts secondary to corticosteroid therapy and irradiation, keratoconjunctivitis sicca and post-intervention retinopathy.[3,29,60,61]

As an alternative to HSCT, ERT has been developed and recommended in patients because of its favourable safety profile.[27] ERT is also used before HSCT to improve the patient's respiratory function and somatic status.[62,63] The administration of purified recombinant enzyme via regular intravenous infusion is now approved for the Hurler/Hurler-Scheie MPS I syndrome (laronidase),[64] MPS II (idursulfase)[65] and MPS VI (galsulfase).[66] Clinically meaningful and sustained improvements in functional capacity and other systemic signs have been observed with ERT in phase III studies.[67-72] With respect to ocular manifestations, stability or improvement of corneal clouding and visual acuity was apparently found in some patients, but controversy about other ocular pathologies such as optic disc changes 
remains.[34,35,69,71,73-75] (Summers CG et al, submitted to Clin Exp Ophthalmol) More assessments are necessary to provide a clear-cut picture of the effects of ERT, and its combination with HSCT, on the course of ocular changes.[4] Limitations of ERT include the risk of allergic or immune reactions related to the administration route (successfully managed by antihistamines and a slower infusion rate), infections associated with regular administration, as well as penetration problems at particular 'privileged sites'.[27] The enzyme, at the doses currently administered, does not cross the blood-brain barrier and presumably, likewise, not the blood-retina barrier to an appreciable extent.[35] Consequently, the ocular involvement in MPS may require novel therapeutic strategies or tailored drug delivery routes, in order to ensure substantial concentrations and sufficient pharmacological effects. Promising attempts in MPS animal models include, amongst others, systemic gene therapy and local injections in the eye.[76,77] (Ponder KP et al, submitted to Clin Exp Ophthalmol) Results of recent phase I clinical trials in patients with Leber congenital amaurosis[78-80] bode well for local gene therapy in (posterior) eye complications associated with other well-defined, single-gene disorders such as MPS. Future interventions with gene therapy will likely change the outcomes of individuals affected with MPS, but early diagnosis will be required for maximum benefit. 


\section{CONCLUDING REMARKS}

The multi-organ involvement and rarity of MPS hamper early recognition of this disease. The diagnosis is often delayed while precious time is spent on expert-to-expert referral.

Ophthalmologists can play a crucial role in diagnosing MPS because they encounter patients with corneal clouding and other ocular problems at a relatively early age, and must be informed regarding the various manifestations in MPS.(Ashworth JL et al, accepted by Clin Exp Ophthalmol)

Diagnosing ocular pathologies can be a challenging task due to concomitant influencing factors (e.g., corneal clouding hampering viewing techniques and corneal thickening with a risk of elevating IOP values) or because the patients' physical or mental incapacities reduce cooperation.(Ashworth JL et al, accepted by Clin Exp Ophthalmol) Similarly, ocular therapies need to take into account the compromised health condition of MPS patients when balancing the benefits and risks of procedures such as corneal transplantation or glaucoma treatment. Systemic therapies that re-establish GAG breakdown (such as HSCT or ERT) could bring relief as part of integrated care, although more investigations are warranted, particularly with regard to their effectiveness on ocular abnormalities in MPS. 


\section{FIGURE LEGENDS}

Figure 1. Patients with MPS VI of varying severity [copyright BioMarin Inc]

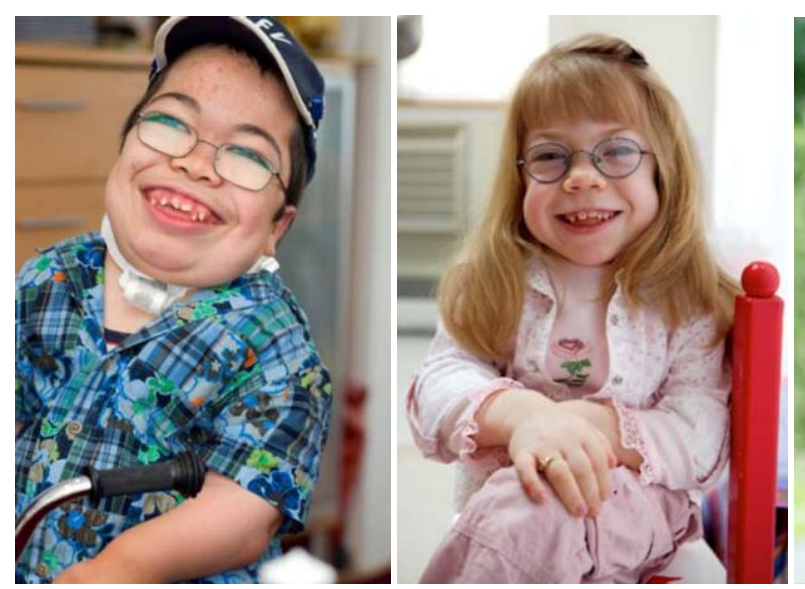

Severe phenotype

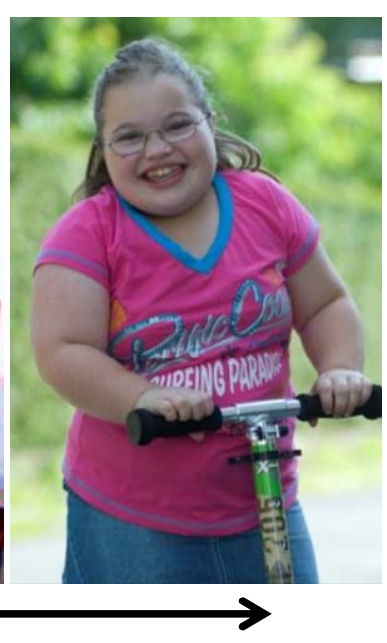

Attenuated phenotype

Figure 2. Ocular features in MPS patients

A) Marked corneal clouding in the right eye of a 12.5-year-old male patient with MPS VI [copyright Fahnehjelm KT]

B) Areas of retinal pigment epithelial atrophy in the right eye of a 15 -year-old patient with MPS I H/S[3]*

C) Bilateral pseudoproptosis exophthalmos due to shallow orbits in a 12.5-year-old male patient with MPS VI [copyright Fahnehjelm KT] 
A

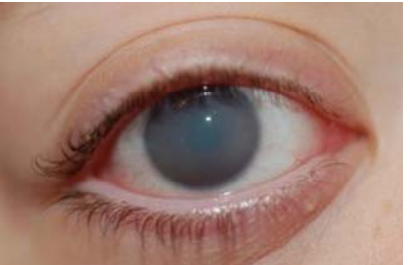

B

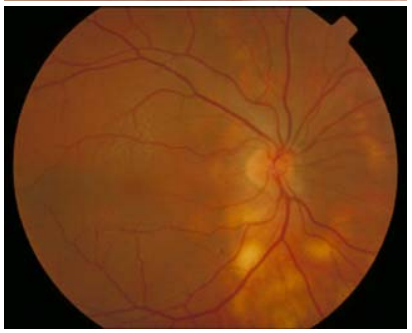

C

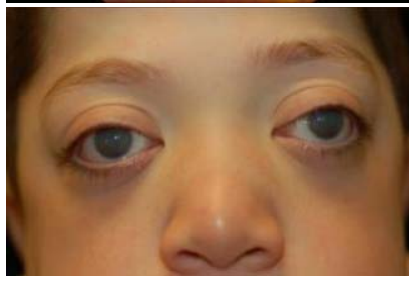

Figure 3. Penetrating keratoplasty with clear donor cornea in a 22-year-old patient with MPS VI (Note that co-existent severe optic atrophy limited visual acuity) [copyright Ashworth JL]

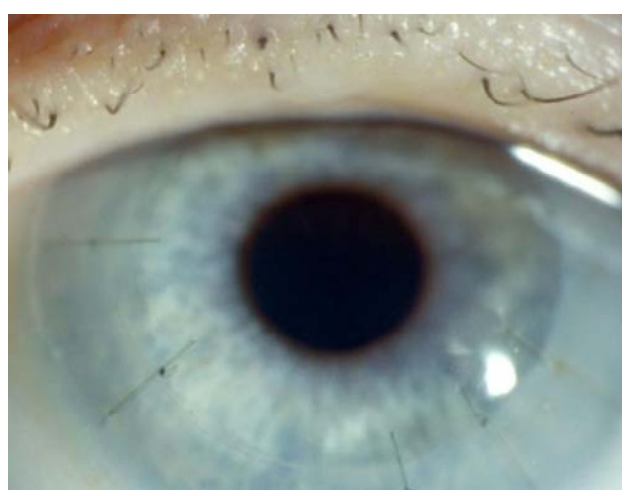

*Footnote to tables and figures: "Reprinted from Survey of Ophthalmology, 51, Ashworth

JL, Biswas S, Wraith E, Lloyd IC, Mucopolysaccharidoses and the eye, 1-17, Copyright (2006), with permission from Elsevier" 


\section{ACKNOWLEDGEMENTS}

The authors are grateful to Ismar Healthcare NV for their writing assistance, which was funded by BioMarin Europe Ltd, London, UK.

The content of the manuscript is based on presentations and discussions during a scientific meeting entitled 'MPS and The Eye', which took place from 7-9 October 2009 in Venice, Italy. The authors would like to thank the other faculty members for their contribution during this meeting, including Prof. A. Auricchio, Dr. B. Bachmann, Prof. M. Busin, Prof. H.S. Dua, Dr. L. Fontana, Prof. R. Giugliani, Prof. J.V. Jester, Dr. G.K. Klintworth, Prof. K. Landau, Mr. A.M. Lobo, Prof. Y. Omidi, Prof. G. Palù, Dr. S. Pitz, Prof. K.P. Ponder, Dr. A. Suppiej, Prof. A.P. Tormene and Dr. C.E. Willoughby. This meeting was supported by an educational grant from BioMarin Europe Ltd, London, UK. BioMarin had no role in the content presented and discussed at the meeting. All authors participated in the development and writing of the manuscript and are fully responsible for its content. BioMarin reviewed the manuscript with respect to the accuracy of statements concerning ERT for MPS VI.

\section{COMPETING INTERESTS}

S Ferrari, D Ponzin, JL Ashworth, KT Fahnehjelm, CG Summers: None

PR Harmatz has provided consulting support to BioMarin Pharmaceutical Inc., Novato, CA and received research grants, speaker's honorarium and travel support from BioMarin.

M Scarpa received unrestricted research and travel grants from BioMarin, Actelion, Genzyme and Shire. 


\section{COPYRIGHT LICENCE STATEMENT}

The Corresponding Author has the right to grant on behalf of all authors and does grant on behalf of all authors, an exclusive licence on a worldwide basis to the BMJ Publishing Group Ltd, and its Licensees to permit this article (if accepted) to be published in the British Journal of Ophthalmology and any other BMJPGL products and to exploit all subsidiary rights, as set out in our licence. 


\section{REFERENCES}

1. Wraith JE. The mucopolysaccharidoses: a clinical review and guide to management. Arch Dis Child 1995;72:263-7.

2. Kenyon KR. Ocular manifestations and pathology of systemic mucopolysaccharidoses. Birth Defects Orig Artic Ser 1976;12:133-53.

3. Ashworth JL, Biswas S, Wraith E, et al. Mucopolysaccharidoses and the eye. Surv Ophthalmol 2006;51:1-17.

4. Ashworth JL, Biswas S, Wraith E, et al. The ocular features of the mucopolysaccharidoses. Eye 2006;20:553-63.

5. Karageorgos L, Brooks DA, Pollard A, et al. Mutational analysis of 105 mucopolysaccharidosis type VI patients. Hum Mutat 2007;28:897-903.

6. Beesley CE, Meaney CA, Greenland G, et al. Mutational analysis of 85 mucopolysaccharidosis type I families: frequency of known mutations, identification of 17 novel mutations and in vitro expression of missense mutations. Hum Genet 2001;109:503-11.

7. Müller-Forell W, Schulze Frenking G, Amraoui Y, et al. Mucopolysaccharidoses (MPS). Clinical and neuroradiological aspects of the different types. Clin Neuroradiol $2007 ; 17: 141-58$

8. de Jong JGN, Wevers RA, Liebrand-van Sambeek R. Measuring urinary glycosaminoglycans in the presence of protein: an improved screening procedure for mucopolysaccharidoses based on dimethylmethylene blue. Clin Chem 1992;38:803-7. 
9. Baehner F, Schmiedeskamp C, Krummenauer F, et al. Cumulative incidence rates of the mucopolysaccharidoses in Germany. J Inherit Metab Dis 2005;28:1011-7.

10. Lin HY, Lin SP, Chuang CK, et al. Incidence of the mucopolysaccharidoses in Taiwan, 1984-2004. Am J Med Genet A 2009;149A:960-4.

11. Nowaczyk MJ, Clarke JTR, Morin JD. Glaucoma as an early complication of Hurler's disease. Arch Dis Child 1988;63:1091-3.

12. Alroy $\mathbf{J}$, Haskins M, Birk DE. Altered corneal stromal matrix organization is associated with mucopolysaccharidosis I, III and VI. Exp Eye Res 1999;68:523-30.

13. Summers CG, Whitley CB, Holland EJ, et al. Dense peripheral corneal clouding in Scheie syndrome. Cornea 1994;13:277-9.

14. Connell P, McCreery K, Doyle A, et al. Central corneal thickness and its relationship to intraocular pressure in mucopolysaccararidoses-1 following bone marrow transplantation. J AAPOS 2008;12:7-10.

15. Summers CG, Purple RL, Krivit W, et al. Ocular changes in the mucopolysaccharidoses after bone marrow transplantation. A preliminary report. Ophthalmology 1989;96:977-85.

16. Martins AM, Dualibi AP, Norato D, et al. Guidelines for the management of mucopolysaccharidosis type I. J Pediatr 2009;155:S32-S46.

17. Pastores GM, Arn P, Beck M, et al. The MPS I registry: design, methodology, and early findings of a global disease registry for monitoring patients with mucopolysaccharidosis type I. Mol Genet Metab 2007;91:37-47. 
18. Azevedo ACMM, Schwartz IV, Kalakun L, et al. Clinical and biochemical study of 28 patients with mucopolysaccharidosis type VI. Clin Genet 2004;66:208-13.

19. Cantor LB, Disseler JA, Wilson II FM. Glaucoma in the Maroteaux-Lamy syndrome. Am J Ophthalmol 1989;108:426-30.

20. Spellacy E, Bankes JLK, Crow J, et al. Glaucoma in a case of Hurler disease. Br J Ophthalmol 1980;64:773-8.

21. Quigley HA, Maumenee AE, Stark WJ. Acute glaucoma in systemic mucopolysaccharidosis I-S. Am J Ophthalmol 1975;80:70-2.

22. Mullaney P, Awad AH, Millar L. Glaucoma in mucopolysaccharidosis 1-H/S. J Pediatr Ophthalmol Strabismus 1996;33:127-31.

23. Sato S, Maeda N, Watanabe H, et al. Multiple iridociliary cysts in patients with mucopolysaccharidoses. Br J Ophthalmol 2002;86:933-4.

24. Schumacher RG, Brzezinska R, Schulze-Frenking G, et al. Sonographic ocular findings in patients with mucopolysaccharidoses I, II and VI. Pediatr Radiol 2008;38:543-50.

25. Vine AK. Uveal effusion in Hunter's syndrome. Evidence that abnormal sclera is responsible for the uveal effusion syndrome. Retina 1986;6:57-60.

26. Collins MLZ, Traboulsi EI, Maumenee IH. Optic nerve head swelling and optic atrophy in the systemic mucopolysaccharidoses. Ophthalmology 1990;97:1445-9.

27. Giugliani R, Harmatz P, Wraith JE. Management guidelines for mucopolysaccharidosis VI. Pediatrics 2007;120:405-18. 
28. Caruso RC, Kaiser-Kupfer MI, Muenzer J, et al. Electroretinographic findings in the mucopolysaccharidoses. Ophthalmology 1986;93:1612-6.

29. Gullingsrud EO, Krivit W, Summers CG. Ocular abnormalities in the mucopolysaccharidoses after bone marrow transplantation. Longer follow-up. Ophthalmology 1998;105:1099-105.

30. Tzetzi D, Hamilton R, Robinson PH, et al. Negative ERGs in mucopolysaccharidoses (MPS) Hurler-Scheie (I-H/S) and Hurler (I-H)-syndromes. Doc Ophthalmol 2007;114:153-8.

31. Anawis MA. Hunter syndrome (MPS II-B): a report of bilateral vitreous floaters and maculopathy. Ophthalmic Genet 2006;27:71-2.

32. Usui T, Shirakashi M, Takagi M, et al. Macular edema-like change and pseudopapilledema in a case of Scheie syndrome. J Clin Neuroophthalmol $1991 ; 11: 183-5$.

33. Fahnehjelm KT, Törnquist AL, Malm G, et al. Ocular findings in four children with mucopolysaccharidosis I-Hurler (MPS I-H) treated early with haematopoietic stem cell transplantation. Acta Ophthalmol Scand 2006;84:781-5.

34. Pitz S, Ogun O, Bajbouj M, et al. Ocular changes in patients with mucopolysaccharidosis I receiving enzyme replacement therapy: a 4-year experience. Arch Ophthalmol 2007;125:1353-6.

35. Pitz S, Ogun O, Arash L, et al. Does enzyme replacement therapy influence the ocular changes in type VI mucopolysaccharidosis? Graefes Arch Clin Exp Ophthalmol 2009;247:975-80. 
36. Tonnu PA, Ho T, Newson T, et al. The influence of central corneal thickness and age on intraocular pressure measured by pneumotonometry, non-contact tonometry, the Tono-Pen XL, and Goldmann applanation tonometry. Br J Ophthalmol 2005;89:851-4.

37. Francis BA, Hsieh A, Lai MY, et al. Effects of corneal thickness, corneal curvature, and intraocular pressure level on Goldmann applanation tonometry and dynamic contour tonometry. Ophthalmology 2007;114:20-6.

38. Lanzl IM, Leroy BP. Ocular features of treatable lysosomal storage disorders - Fabry disease, mucopolysaccharidoses I, II and VI and Gaucher disease. Eur Ophthalmic Rev 2008;2:55-62.

39. Yoon MK, Chen RW, Hedges TR, III, et al. High-speed, ultrahigh resolution optical coherence tomography of the retina in Hunter syndrome. Ophthalmic Surg Lasers Imaging 2007;38:423-8.

40. Grupcheva CN, Craig JP, McGhee CNJ. In vivo microstructural analysis of the cornea in Scheie's syndrome. Cornea 2003;22:76-9.

41. Mocan MC, Eldem B, Irkec M. In vivo confocal microscopic findings of two siblings with Maroteaux-Lamy syndrome. Cornea 2007;26:90-3.

42. Patel DV, Ku JYF, Kent-Smith B, et al. In vivo microstructural analysis of the cornea in Maroteaux-Lamy syndrome. Cornea 2005;24:623-5.

43. Belani KG, Krivit W, Carpenter BLM, et al. Children with mucopolysaccharidosis: perioperative care, morbidity, mortality, and new findings. J Pediatr Surg $1993 ; 28: 403-8$. 
44. Walker RWM, Darowski M, Morris P, et al. Anaesthesia and mucopolysaccharidoses. A review of airway problems in children. Anaesthesia 1994;49:1078-84.

45. Sjøgren P, Pedersen T, Steinmetz H. Mucopolysaccharidoses and anaesthetic risks. Acta Anaesthesiol Scand 1987;31:214-8.

46. Diaz JH, Belani KG. Perioperative management of children with mucopolysaccharidoses. Anesth Analg 1993;77:1261-70.

47. Nischal KK. Pediatric keratoplasty. Techniques in Ophthalmology 2003;1:119-26.

48. Bergwerk K, Falk RE, Glasgow BJ, et al. Corneal transplantation in a patient with mucopolysaccharidosis type VII (Sly disease). Ophthalmic Genet 2000;21:17-20.

49. Käsmann-Kellner B, Weindler J, Pfau B, et al. Ocular changes in mucopolysaccharidosis IV A (Morquio A syndrome) and long-term results of perforating keratoplasty. Ophthalmologica 1999;213:200-5.

50. Varssano D, Cohen EJ, Nelson LB, et al. Corneal transplantation in Maroteaux-Lamy syndrome. Arch Ophthalmol 1997;115:428-9.

51. Uçakhan ÖÖ, Brodie SE, Desnick R, et al. Long-term follow-up of corneal graft survival following bone marrow transplantation in the Maroteaux-Lamy syndrome. CLAO J 2001;27:234-7.

52. Rosen DA, Edmison DR, Robertson DM. Five year maintenance of corneal graft normality in systemic mucopolysaccharidosis. Can J Ophthalmol 1972;7:445-53. 
53. Naumann G. Clearing of cornea after perforating keratoplasty in mucopolysaccharidosis type VI (Maroteaux-Lamy syndrome). N Engl J Med $1985 ; 312: 995$.

54. Schwartz MF, Werblin TP, Green WR. Occurrence of mucopolysaccharide in corneal grafts in the Maroteaux-Lamy syndrome. Cornea 1985;4:58-66.

55. Schwartz K, Budenz D. Current management of glaucoma. Curr Opin Ophthalmol 2004;15:119-26.

56. Harmatz P. Entering a new treatment age for mucopolysaccharidosis VI disease: a search for better markers of disease progression and response to treatment. J Pediatr (Rio J) 2008;84:103-6.

57. Muenzer J, Wraith JE, Clarke LA. Mucopolysaccharidosis I: management and treatment guidelines. Pediatrics 2009;123:19-29.

58. Gabrielli O, Clarke LA, Bruni S, et al. Enzyme-replacement therapy in a 5-month-old boy with attenuated presymptomatic MPS I: 5-year follow-up. Pediatrics 2010;125:e183-e187.

59. McGill JJ, Inwood AC, Coman DJ, et al. Enzyme replacement therapy for mucopolysaccharidosis VI from 8 weeks of age - a sibling control study. Clin Genet 2010;77:492-8.

60. Fahnehjelm KT, Törnquist AL, Winiarski J. Dry-eye syndrome after allogeneic stemcell transplantation in children. Acta Ophthalmol 2008;86:253-8. 
61. Fahnehjelm KT, Törnquist AL, Olsson M, et al. Visual outcome and cataract development after allogeneic stem-cell transplantation in children. Acta Ophthalmol Scand 2007;85:724-33.

62. Cox-Brinkman J, Boelens JJ, Wraith JE, et al. Haematopoietic cell transplantation (HCT) in combination with enzyme replacement therapy (ERT) in patients with Hurler syndrome. Bone Marrow Transplant 2006;38:17-21.

63. Wynn RF, Mercer J, Page J, et al. Use of enzyme replacement therapy (Laronidase) before hematopoietic stem cell transplantation for mucopolysaccharidosis I: experience in 18 patients. J Pediatr 2009;154:135-9.

64. Aldurazyme ${ }^{\circledR}$, BioMarin Pharmaceutical Inc, Novato, CA, USA.

65. Elaprase $^{\circledR}$, Shire Human Genetic Therapies Inc, Cambridge, CA, USA.

66. Naglazyme ${ }^{\circledR}$, BioMarin Pharmaceutical Inc, Novato, CA, USA.

67. Harmatz P, Giugliani R, Schwartz I, et al. Enzyme replacement therapy for mucopolysaccharidosis VI: a phase 3, randomized, double-blind, placebo-controlled, multinational study of recombinant human $\mathrm{N}$-acetylgalactosamine 4-sulfatase (recombinant human arylsulfatase B or rhASB) and follow-on, open-label extension study. J Pediatr 2006;148:533-9.

68. Harmatz P, Giugliani R, Schwartz IVD, et al. Long-term follow-up of endurance and safety outcomes during enzyme replacement therapy for mucopolysaccharidosis VI: final results of three clinical studies of recombinant human $\mathrm{N}$-acetylgalactosamine 4sulfatase. Mol Genet Metab 2008;94:469-75. 
69. Scarpa M, Barone R, Fiumara A, et al. Mucopolysaccharidosis VI: the Italian experience. Eur J Pediatr 2009;168:1203-6.

70. Muenzer J, Wraith JE, Beck M, et al. A phase II/III clinical study of enzyme replacement therapy with idursulfase in mucopolysaccharidosis II (Hunter syndrome). Genet Med 2006;8:465-73.

71. Clarke LA, Wraith JE, Beck M, et al. Long-term efficacy and safety of laronidase in the treatment of mucopolysaccharidosis I. Pediatrics 2009;123:229-40.

72. Wraith JE, Clarke LA, Beck M, et al. Enzyme replacement therapy for mucopolysaccharidosis I: a randomized, double-blinded, placebo-controlled, multinational study of recombinant human $\alpha$-L-iduronidase (laronidase). J Pediatr 2004;144:581-8.

73. Wraith JE. The first 5 years of clinical experience with laronidase enzyme replacement therapy for mucopolysaccharidosis I. Expert Opin Pharmacother 2005;6:489-506.

74. Kakkis ED, Muenzer J, Tiller GE, et al. Enzyme-replacement therapy in mucopolysaccharidosis I. N Engl J Med 2001;344:182-8.

75. Koseoglu ST, Harmatz P, Turbeville S, et al. Reversed papilledema in an MPS VI patient with galsulfase $\left(\right.$ Naglazyme $\left.^{\circledR}\right)$ therapy. Int Ophthalmol 2009;29:267-9.

76. Ponder KP, Haskins ME. Gene therapy for mucopolysaccharidosis. Expert Opin Biol Ther 2007;7:1333-45.

77. Colella P, Cotugno G, Auricchio A. Ocular gene therapy: current progress and future prospects. Trends Mol Med 2009;15:23-31. 
78. Bainbridge JWB, Smith AJ, Barker SS, et al. Effect of gene therapy on visual function in Leber's congenital amaurosis. N Engl J Med 2008;358:2231-9.

79. Hauswirth WW, Aleman TS, Kaushal S, et al. Treatment of Leber congenital amaurosis due to RPE65 mutations by ocular subretinal injection of adeno-associated virus gene vector: short-term results of a phase I trial. Hum Gene Ther 2008;19:97990.

80. Maguire AM, Simonelli F, Pierce EA, et al. Safety and efficacy of gene transfer for Leber's congenital amaurosis. N Engl J Med 2008;358:2240-8. 

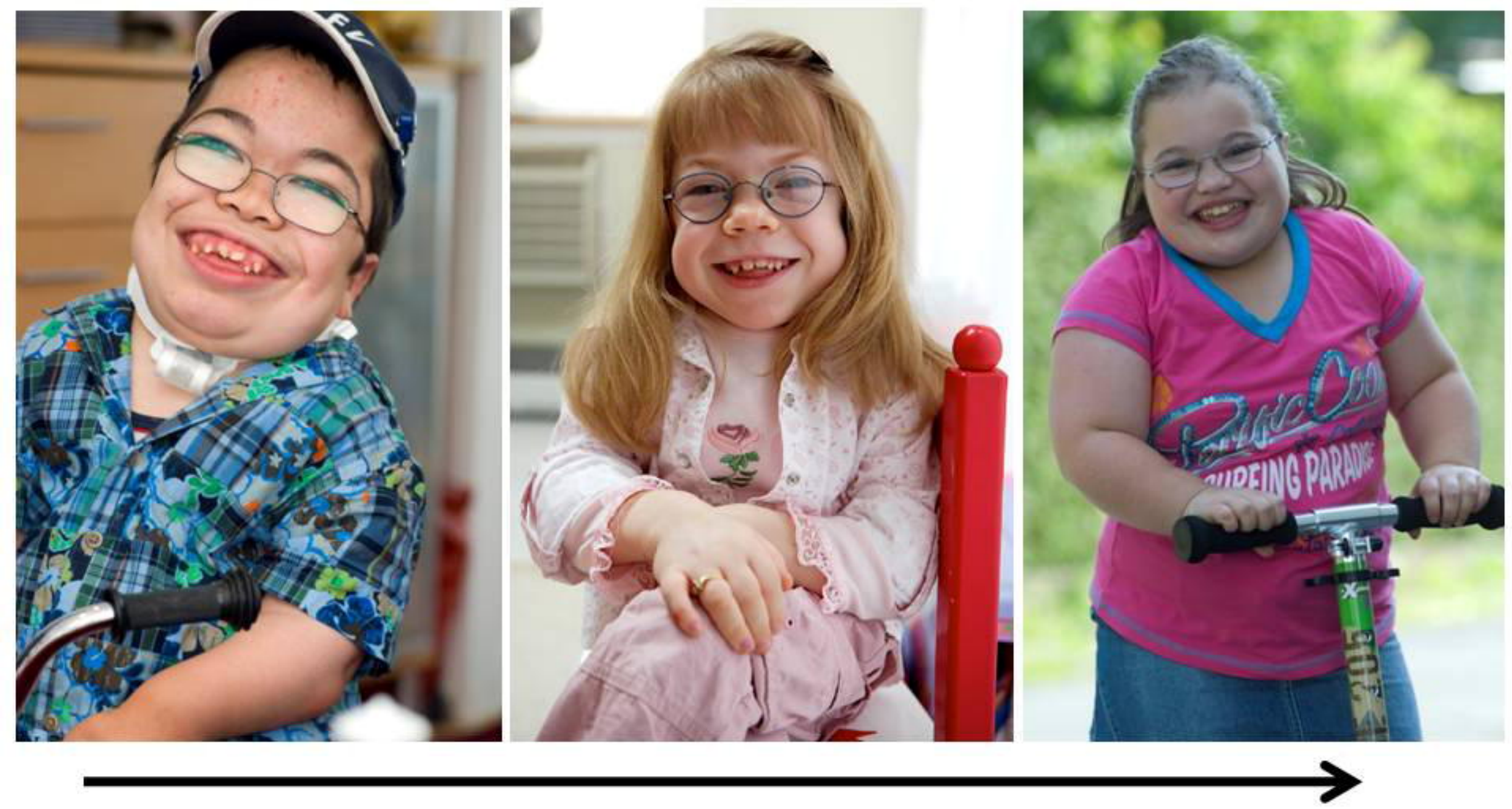

Severe phenotype

Attenuated phenotype 
